\title{
The contribution of transgenic plants to better health through improved nutrition: opportunities and constraints
}

\author{
Eduard Pérez-Massot · Raviraj Banakar · Sonia Gómez-Galera $\cdot$ Uxue Zorrilla-López $\cdot$ Georgina Sanahuja $\cdot$ \\ Gemma Arjó • Bruna Miralpeix • Evangelia Vamvaka • Gemma Farré • Sol Maiam Rivera • \\ Svetlana Dashevskaya · Judit Berman · Maite Sabalza - Dawei Yuan · Chao Bai - Ludovic Bassie · \\ Richard M. Twyman $\cdot$ Teresa Capell $\cdot$ Paul Christou $\cdot$ Changfu Zhu
}

Received: 11 February 2012/Accepted: 2 August 2012/Published online: 29 August 2012

(C) Springer-Verlag 2012

\begin{abstract}
Malnutrition is a prevalent and entrenched global socioeconomic challenge that reflects the combined impact of poverty, poor access to food, inefficient food distribution infrastructure, and an over-reliance on subsistence mono-agriculture. The dependence on staple cereals lacking many essential nutrients means that malnutrition is endemic in developing countries. Most individuals lack diverse diets and are therefore exposed to nutrient deficiencies. Plant biotechnology could play a major role in combating malnutrition through the engineering of nutritionally enhanced crops. In this article, we discuss different approaches that can enhance the nutritional content of staple crops by genetic engineering (GE) as well as the functionality and safety assessments required before
\end{abstract}

Eduard Pérez-Massot and Raviraj Banakar contributed equally to this work.

Special section: "Foodomics"; Guest Editors Dr. A. Bordoni and F. Capozzi.

Electronic supplementary material The online version of this article (doi:10.1007/s12263-012-0315-5) contains supplementary material, which is available to authorized users.

E. Pérez-Massot · R. Banakar · S. Gómez-Galera .

U. Zorrilla-López · G. Sanahuja - B. Miralpeix · E. Vamvaka ·

G. Farré · S. Dashevskaya · J. Berman · M. Sabalza .

D. Yuan · C. Bai · L. Bassie · T. Capell · P. Christou ( $\square)$.

C. Zhu $(\square)$

Department of Plant Production and Forestry Science, ETSEA,

University of Lleida-Agrotecnio Center, Av. Alcalde Rovira

Roure, 191, 25198 Lleida, Spain

e-mail: christou@pvcf.udl.es

C. Zhu

e-mail: zhu@pvcf.udl.cat

G. Arjó

Department of Medicine, University of Lleida, Lleida, Spain nutritionally enhanced GE crops can be deployed in the field. We also consider major constraints that hinder the adoption of GE technology at different levels and suggest policies that could be adopted to accelerate the deployment of nutritionally enhanced GE crops within a multicomponent strategy to combat malnutrition.

Keywords Transgenic crops - Micronutrients .

Food security · Vitamins · Minerals · Genetic engineering

\section{Introduction}

Food security is one of the pillars of health and well-being in society because humans rely on food not only to supply energy but also for essential nutrients that maintain the immune system and keep the body in a good state of repair. Adequate nutrition therefore correlates with lower morbidity and mortality from both infectious and non-infectious diseases and is particularly important in children and pregnant women where the lack of essential nutrients can lead to irreversible physical and mental damage during development (Hoddinott et al. 2008).

S. M. Rivera

Chemistry Department, ETSEA, University of Lleida,

25198 Lleida, Spain

R. M. Twyman

Department of Biological Sciences, University of Warwick,

Coventry CV4 7AL, UK

P. Christou

Institució Catalana de Recerca i Estudis Avançats,

Passeig Lluís Companys 23, 08010 Barcelona, Spain 
Malnutrition is more prevalent in the developing world because it often reflects the lack of access to nutritious food. This in turn is frequently caused by poverty, which often occurs due to ill health and an inability to work, the typical consequences of malnutrition. Poverty, malnutrition and poor health therefore form a self-reinforcing cycle from which many people (and in some cases entire populations) find it impossible to escape (Farré et al. 2011b).

Almost $50 \%$ of the world's population is currently affected by malnutrition (Christou and Twyman 2004). The majority are subsistence farmers who depend entirely on staple cereal crops such as maize or rice, which are deficient in several essential nutrients (Zhu et al. 2007). The poverty-malnutrition-disease cycle needs to be broken by multipoint interventions that provide direct, effective and sustainable approaches to increase the economic welfare of the world's poorest people, including the provision of drugs and vaccines that tackle poor health, and adequate access to nutritious food (Perseley 2000). Although there are many global initiatives promoting short and mid-term strategies that tackle poverty, food insecurity/malnutrition and disease, we need sustainable solutions that provide the means for the world's poor to build their own healthy societies, as envisaged by the Millennium Development Goals (Yuan et al. 2011).

Strategies to tackle malnutrition fall into three major categories (Gómez-Galera et al. 2010). The most desirable approach is to increase the diversity of food intake but this is impractical in many developing-country settings, particularly for low-income populations. In some cases it may be possible to change local food-processing conventions to prevent the loss of nutrients during preparation (Hotz and Gibson 2007) or to promote certain styles of preparation that maximize nutritional bioavailability (Yang and Tsou 2006).

The second approach is to add nutrients to the diet artificially, either by providing supplements (Supplementation) or by the fortification of basic food products such as salt and flour, but it is unsustainable over the longer term because it relies on a robust distribution infrastructure and on consumer compliance (Hotz and Brown 2004). Fortification is more sustainable, and there have been remarkable successes, such as the provision of iodine-fortified salt, and wheat flour double-fortified with iron and folate (Rosenberg 2005). However, this strategy also requires government coordination and a distribution infrastructure and is therefore unsuitable for those parts of the developing world relying on subsistence agriculture.

The final strategy is known as biofortification, in which crops are modified or treated to accumulate additional nutrients at source (Zhu et al. 2007). In some cases biofortification can be achieved by adding nutrients to fertilizers, an approach that has been extraordinarily successful to increase the availability of zinc and selenium (Lyons et al. 2003). However, this is not suitable for iron, because it is immobilized in the soil (Gómez-Galera et al. 2012a), or for essential organic nutrients (vitamins and essential amino acids and fatty acids) which are the products of plant metabolism. It may be possible to increase the content of organic nutrients by conventional breeding if there is sufficient genetic diversity in existing germplasm, although it would take many generations to introgress these traits into local elite breeding varieties (Welch and Graham 2005). The alternative is genetic engineering (GE) technology, which can introduce genes from any source directly into the local varieties used by subsistence farmers, to increase the levels of organic and/or mineral nutrients. First-generation GE crops have already shown their potential to enhance agricultural productivity and reduce poverty in developing countries (Christou and Twyman 2004, Farré et al. 2010a, 2011b). A second generation of GE crops is now under development that can address nutritional requirements directly by contributing to multipoint intervention strategies (Yuan et al. 2011). As well as offering an unrestricted choice of genes for nutritional improvement, the GE approach allows nutritional traits to be targeted to specific organs (e.g., cereal seeds) and multiple traits can be combined in the same plants without complex breeding programs (Zhu et al. 2007; Naqvi et al. 2009a).

\section{GE strategies to enhance the content of organic micronutrients}

Humans can synthesize almost all the organic compounds needed for normal physiological activity but a small number of specific molecules known as essential nutrients are required in the diet (Online Resource 1). Some of these essential nutrients are amino acids or fatty acids; the rest are chemically diverse but are grouped together as vitamins. All GE strategies focusing on essential organic micronutrients involve the modulation of plant metabolism.

\section{Vitamin A}

The reduced form of vitamin A (retinal) is required for the production of rhodopsin, which is essential for sight and also helps to maintain epithelial and immune cells. The acidic form (retinoic acid) is a morphogen in development. Humans can produce retinal and retinoic acid if provided with a source of retinol or one of its esters, which are abundant in meat and dairy products. However, retinal can also be synthesized directly from $\beta$-carotene (also known as pro-vitamin A) which is produced mainly by plants and photosynthetic microbes, but also some non-photosynthesizing organisms (Botella-Pavía and Rodríguez-Concepción 
2006). Vitamin A deficiency (VAD) is one of the most prevalent deficiency diseases in developing countries, affecting more than 4 million children each year, up to 500,000 of whom become partially or totally blind (Harrison 2005).

The amount of $\beta$-carotene produced by plants can be enhanced by increasing flux through the carotenoid pathway (Online Resource 2), for example, by increasing the availability of carotenoid precursors, by expressing enzymes in the early part of the pathway between GGPP and lycopene, by increasing metabolic flux in the $\beta$-branch by favoring LYCB activity at the expense of LYCE, or by increasing the sink capacity for carotenoids to remove feedback limitations (Zhu et al. 2009; Farré et al. 2010b; 2011a; Bai et al. 2011). The overexpression of DXP synthase in tomato is an example of the first strategy, producing a carotenoid precursor that increases flux in the entire pathway and enhances the total carotenoid content (Enfissi et al. 2005). Cassava roots expressing the bacterial $\mathrm{CrtB}$ gene accumulated up to $21 \mu \mathrm{g} / \mathrm{g}$ of carotenoids, a 34-fold increase with respect to the wild type (Welsch et al. 2010). The replacement of the daffodil gene with its maize ortholog is the basis of Golden Rice 2, which produces up to $37 \mu \mathrm{g}$ of carotenoids per gram dry weight (DW) of grain, of which $31 \mu \mathrm{g} / \mathrm{g}$ is $\beta$-carotene (Paine et al. 2005). The same genes expressed in maize have yielded kernels containing up to $57.3-60 \mu \mathrm{g} / \mathrm{g}$ dry weight of $\beta$-carotene (Zhu et al. 2008; Naqvi et al. 2009b; Table 1). The third strategy is exemplified by Golden Potato, where expression of three Erwinia genes encoding phytoene synthase (CrtB), phytoene desaturase ( $\mathrm{CrtI}$ ) and lycopene beta-cyclase (CrtY) lead to the diversion of carotenoid synthesis from the $\alpha$ - to the $\beta$-branch (Online Resource 2), resulting in the accumulation of $47 \mu \mathrm{g} / \mathrm{g}$ DW of $\beta$-carotene (Diretto et al. 2007, Table 1). Potato also provides a good example of the fourth strategy. The expression of the cauliflower $\mathrm{Or}$ gene in tubers increased the storage capacity for carotenoids by promoting the formation of chromoplasts, generating transgenic potatoes with orange tuber flesh containing 10 times the normal amount of $\beta$-carotene (Lopez et al. 2008, Table 1).

\section{Vitamin C}

Ascorbate (vitamin C) is an antioxidant and also cofactor of several enzymes, including those required for the synthesis of collagen, carnitine, cholesterol, and certain amino acid hormones. Vitamin $\mathrm{C}$ deficiency causes the ulceration disease scurvy, reflecting the breakdown of connective tissues (Bartholomew 2002).

There are several biosynthetic pathways that generate ascorbate in plants, and when ascorbate is oxidized it can be recycled through an additional pathway with glutathione as the reductant (Online Resource 3). The amount of ascorbate accumulating in plants can therefore be enhanced not only by increasing its biosynthesis but also the rate at which the molecule is recycled. In the first approach, the overexpression of L-gulono $\gamma$-lactone oxidase (GLOase) in lettuce resulted in the accumulation of up to $580 \mathrm{nmol} / \mathrm{g}$ fresh weight of ascorbate, a sevenfold improvement (Jain and Nessler 2000). A twofold increase was achieved by expressing the same gene in potato tubers (Hemavathi et al. 2010). Multivitamin maize expressing the rice dhar gene from the ascorbate recycling pathway accumulated six times the normal level of ascorbate (Naqvi et al. 2009b, Table 1).

\section{Vitamin B9}

Folate (vitamin B9) is a tripartite molecule combining pterin, p-aminobenzoate (PABA) and one or more glutamate moieties, which are derived from three separate metabolic pathways in different subcellular compartments (Online Resource 4). Folate is the source of tetrahydrofolate, which is essential for DNA synthesis and many other core metabolic reactions. In adults, folate deficiency causes macrocytic anemia and elevated levels of homocysteine, but the impact on pregnant women is much more severe, leading to the neural tube defect spina bifida in the fetus (Scholl and Johnson 2000).

Moderate increases in folate levels have been achieved by modifying the pterin and PABA pathways individually, but increasing the flux through one pathway only reveals bottlenecks in the other. Díaz de la Garza et al. (2007) crossed two transgenic tomato lines, one expressing GCH1 which enhanced the cytosolic (pterin) branch, and the other ADCS1 which enhanced the PABA branch. In the individual lines, the maximum enhancement was double the normal level of folate. However, combining the two transgenes in a single line released the bottlenecks in both branches simultaneously and achieved a 25 -fold increase in folate levels. The same strategy in rice endosperm resulted in a 100-fold increase in folate levels because the base levels were lower than in tomato, indicating how powerful this strategy could be in developing-country settings where rice is the staple diet (Storozhenko et al. 2007, Table 1).

\section{Vitamin E}

Vitamin E comprises eight related molecules known as tocochromanols. These are formed from a chromanol head decorated with methyl groups (to yield $\alpha, \beta, \gamma$, and $\delta$ derivatives) plus either a phytyl tail to produce the tocopherols, or a geranylgeranyl tail to produce the tocotrienols (DellaPenna and Pogson 2006). The tocochromanols are powerful antioxidants that protect fatty acids, low- 
Table 1 Transgenic crops enhanced for mineral and vitamin content

\begin{tabular}{|c|c|c|c|c|}
\hline Nutrient & Species & Genes used & $\begin{array}{l}\text { Total increase (fold increase } \\
\text { over wild type) }\end{array}$ & References \\
\hline \multirow[t]{11}{*}{ Vitamin A } & Maize (Zea mays) & PacrtB and PacrtI & 33.6 g/g DW (34) & Aluru et al. (2008) \\
\hline & Maize (Z. mays) & $\begin{array}{l}\text { Zmpsy1, PacrtI, PcrtW, } \\
\quad \text { Gllycb }\end{array}$ & $146.7 \mu \mathrm{g} / \mathrm{g}$ DW (133) & Zhu et al. (2008) \\
\hline & Maize (Z. mays) & Zmpsyl, PacrtI & $163.2 \mu \mathrm{g} / \mathrm{g}$ DW (112) & Naqvi et al. (2009b) \\
\hline & Wheat (Triticum aestivum) & Zmpsyl, PacrtI & $4.96 \mu \mathrm{g} / \mathrm{g}$ DW (10.8) & Cong et al. (2009) \\
\hline & Potato (Solanum tuberosum) & $E u C r t B, E u C r t I, E u C r t Y$ & $114 \mu \mathrm{g} / \mathrm{g}$ DW (20) & Diretto et al. (2007) \\
\hline & Potato (S. tuberosum) & $\mathrm{BoOr}$ & $28.22 \mu \mathrm{g} / \mathrm{g}$ DW (6) & Lopez et al. (2008) \\
\hline & Potato (S. tuberosum) & $A t Z E P$ & $60.8 \mu \mathrm{g} / \mathrm{g}$ DW (5.7) & Romer et al. (2002) \\
\hline & Potato (S. tuberosum) & PacrtB & $35.5 \mu \mathrm{g} / \mathrm{g}$ DW (6.3) & Ducreux et al. (2005) \\
\hline & Cassava (Manihot esculenta) & PacrtB & 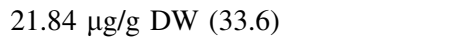 & Welsch et al. (2010) \\
\hline & Rice (Oryza sativa) & Nppsy1, EucrtI & $1.6 \mu \mathrm{g} / \mathrm{g}$ & Ye et al. (2000) \\
\hline & Rice $(O$. sativa $)$ & Zmppsy1, EucrtI & $37 \mu \mathrm{g} / \mathrm{g}(23)$ & Paine et al. (2005) \\
\hline \multirow[t]{3}{*}{ Vitamin $\mathrm{C}$} & Corn (Z. mays) & Osdhar & $110 \mu \mathrm{g} / \mathrm{g}$ DW (6) & Naqvi et al. (2009b) \\
\hline & $\begin{array}{l}\text { Tomato (Solanum } \\
\text { lycopersicum) }\end{array}$ & Acggp & 46-111 mg/100 g FW (3-6) & Bulley et al. (2011) \\
\hline & Potato (S. tuberosum) & StVTC2A & 1.65 mg/g FW (3) & Bulley et al. (2011) \\
\hline \multirow[t]{2}{*}{ Folic acid } & Rice $(O$. sativa $)$ & Atgtpchi, Atadcs & 38.3 nmol/g (100) & $\begin{array}{l}\text { Storozhenko et al. } \\
\text { (2007) }\end{array}$ \\
\hline & Tomato (S. lycopersicum) & Atgch, Atadcs 1 & $25 \mathrm{nmol} / \mathrm{g}(25)$ & $\begin{array}{l}\text { Storozhenko et al. } \\
\text { (2007) }\end{array}$ \\
\hline \multirow[t]{5}{*}{ Iron $(\mathrm{Fe})$} & Rice $(O$. sativa $)$ & Osnas 2 & $19 \mu \mathrm{g} / \mathrm{g} \mathrm{DW}$ in polished seeds (4.2) & Johnson et al. (2011) \\
\hline & Rice (O. sativa) & $\begin{array}{l}\text { Gm ferritin, Af phytase, } \\
\text { Osnas } 1\end{array}$ & $7 \mu \mathrm{g} / \mathrm{g}$ DW in polished seeds $(4-6.3)$ & Wirth et al. (2009) \\
\hline & Rice $(O$. sativa $)$ & Activation tagging of Osnas 3 & 32 in $\mu \mathrm{g} / \mathrm{g}$ DW in dehusked (2.9) & Lee et al. (2009) \\
\hline & Corn (Z. mays) & Gm ferritin and Af phytase & $30 \mu \mathrm{g} / \mathrm{g}$ DW in whole seed (2) & Drakakaki et al. (2005) \\
\hline & Cassava (M. esculenta) & Crfeal & $40 \mu \mathrm{g} / \mathrm{g} \mathrm{DW}$ in tuber & Sayre et al. (2011) \\
\hline \multirow[t]{5}{*}{ Zinc $(\mathrm{Zn})$} & Rice $(O$. sativa) & Activation tagging of Osnas 2 & $\begin{array}{l}40-45 \mu \mathrm{g} / \mathrm{g} \text { DW in polished seeds } \\
(2.9)\end{array}$ & Lee et al. (2011) \\
\hline & Rice $(O$. sativa $)$ & Osnas 2 & $\begin{array}{l}52-76 \mu \mathrm{g} / \mathrm{g} \text { DW in polished seeds } \\
(2.2)\end{array}$ & Johnson et al. (2011) \\
\hline & Rice $(O$. sativa) & $\begin{array}{l}\text { Gm ferritin, Af phytase, } \\
\text { Osnas } 1\end{array}$ & $35 \mu \mathrm{g} / \mathrm{g}$ DW in polished seeds (1.6) & Wirth et al. (2009) \\
\hline & Cassava (M. esculenta) & Atzat1 & Tuber (4) & Sayre et al. (2011) \\
\hline & Cassava (M. esculenta) & Atzip & Tuber $(2-10)$ & Sayre et al. (2011) \\
\hline \multirow[t]{2}{*}{$\begin{array}{l}\text { Selenium } \\
\quad(\mathrm{Se})\end{array}$} & $\begin{array}{l}\text { Indian Mustard (Brassica } \\
\text { juncea) }\end{array}$ & Ataps1 & $(2-3)$ & $\begin{array}{l}\text { Pilion-Smits et al. } \\
\text { (1999) }\end{array}$ \\
\hline & Indian mustard (B. juncea) & Absmt1 & $(2-4)$ & LeDuc et al. (2004) \\
\hline \multirow{4}{*}{$\begin{array}{l}\text { Calcium } \\
\text { (Ca) }\end{array}$} & Carrot (Daucus carota) & scaxl & 3.9 mg/g DW (1.6) & Park et al. (2004) \\
\hline & Lettuce (Lactuca sativa) & scaxl & 18.9 mg/g DW (1.3) & Park et al. (2009) \\
\hline & Potato (S. tuberosum) & scaxl & 1.7 mg/g DW (in tuber) (3) & Park et al. (2005) \\
\hline & & $\operatorname{cax} 2 b$ chimeric & 2.5 mg/g DW (3) & Kim et al. (2006) \\
\hline
\end{tabular}

density lipoproteins (LDLs) and other components of cell membranes from oxidative stress.

Plants can be engineered to accumulate higher levels of vitamin $\mathrm{E}$ by overexpressing genes involved in tocochromanol synthesis (Online Resource 5). This can be achieved either by increasing the total tocochromanol content or skewing tocochromanol synthesis toward the more potent isomers, particularly $\alpha$-tocopherol which is absorbed more efficiently by humans. For example, Cho et al. (2005) increased the $\alpha / \gamma$ tocopherol ratio in transgenic lettuce plants by expressing the Arabidopsis $\gamma$-tocopherol methyltransferase $(\gamma$-TMT), and achieved near complete 
conversion to $\alpha$-tocopherol in the best-performing transgenic lines. Similarly, Tavya et al. (2007) reported a 10.4fold increase in $\alpha$-tocopherol levels and a 14.9-fold increase in $\beta$-tocopherol levels in soybean seeds expressing Perilla frutescens $\gamma$-TMT. The constitutive expression of two Arabidopsis cDNA clones encoding $\rho$-hydroxyphenylpyruvate dioxygenase (HPPD) and 2-methyl-6-phytylplastoquinol methyltransferase (MPBQ MT) increased the tocopherol content by threefold in transgenic maize (Naqvi et al. 2011). Overexpression of Arabidopsis HPPD in rice grains shifted tocopherol synthesis from the $\gamma$ to the $\alpha$ form with no increase in absolute tocopherol levels (Farré et al. in press).

\section{Essential amino acids}

Nine of the 20 standard amino acids are constitutive essential nutrients because they cannot be synthesized de novo by humans, and others are essential under certain circumstances, such as child development or in the context of metabolic disorders. The most relevant examples are lysine, threonine, tryptophan, methionine and cysteine because staple cereals are poor sources of lysine and threonine, and staple legumes are poor sources of tryptophan, methionine and/or cysteine (Zhu et al. 2007).

Two GE strategies have been used to tackle amino acid deficiency: (1) engineering plants to produce proteins containing essential amino acids; and (2) engineering amino acid metabolism to increase the availability of essential amino acids in the free amino acid pool. Lysine was the first target in both strategies. One of the earliest attempts to overcome the poor nutritional value of cereal proteins was the expression of lysine-rich pea legumin in cereal endosperm, which resulted in transgenic rice and wheat grain protein containing up to $4.2 \%$ lysine (Sindhu et al. 1997; Stöger et al. 2001). More significant improvements were achieved by adding lysine residues to endogenous cereal storage proteins for example, 12 residues added to barley hordothionine to produce HT12, and eight added to barley high lysine protein to produce HL8 (Jung and Carl 2000). When expressed in maize along with the bacterial enzyme dihydrodipicolinate synthase (DHPS) the total lysine content was four times the normal amount, accounting for $0.8 \%$ of total protein composition. Another lysine-rich storage protein (sb401) increased the lysine content in maize seeds by $55 \%$ (Yu et al. 2004). Similar improvements have been achieved by expressing lysinerich animal proteins such as porcine $\alpha$-lactalbumin, which increased the lysine content in maize by $47 \%$ (Bicar et al. 2008). Maize seeds containing up to $26 \%$ lysine have also been produced by expressing a heterotypical Arabidopsis lysyl tRNA synthetase, which inserts lysine residues in place of other amino acids during the synthesis of seed storage proteins (Wu et al. 2007). Finally, the lysine content of maize has been increased by using RNA interference to silence one of the zein storage protein genes allowing the protein complement to be filled with lysinerich storage proteins (Segal et al. 2003).

One of the success stories in terms of storage protein engineering involves the expression in staple crops of Amaranthus hypochondriacus seed storage protein, which is rich in all the essential amino acids and has a composition close to ideal for humans. Transgenic maize seeds expressing the $\mathrm{AH}$ protein contained up to $32 \%$ more protein than wild-type seeds and contained higher levels of lysine, tryptophan and isoleucine (Rascón-Cruz et al. 2004). Similarly transgenic potato tubers expressing $\mathrm{AH}$ contained $45 \%$ more protein than normal (Chakraborty et al. 2000) and transgenic wheat seeds contained nearly $2.5 \% \mathrm{AH}$ as a proportion of total seed protein, increasing the levels of lysine to $6.4 \%$ and tyrosine to $3.8 \%$ (Tamás et al. 2009).

Expression of feedback-insensitive dihydrodipicolinate synthase (DHPS) in maize increased lysine levels from $<2 \%$ to $\sim 30 \%$ of the free amino acid pool, with concomitant increases in threonine (Frizzi et al. 2008). The key rate-limiting enzyme in tryptophan synthesis is anthranilate synthase, which catalyzes the conversion of chorismate to anthranilate, and tryptophan levels in rice have been increased more than 400-fold by expressing a feedback-insensitive version (Wakasa et al. 2006). Tryptophan levels also increased 30-fold in potato tubers (Yamada et al. 2004) and 20-fold in soybean seeds (Ishimoto et al. 2010) expressing feedback-insensitive AS.

Essential fatty acids

Humans can synthesize most fatty acids de novo but the health-promoting $\omega-3$ and $\omega-6$ polyunsaturated fatty acids (PUFAs) are exceptions that need to be sourced from the diet (Djoussé et al. 2011). Once acquired, simple $\omega-3$ PUFAs such as $\alpha$-linolenic acid can be converted into more complex very-long-chain polyunsaturated fatty acids (VLC-PUFAs) such as arachidonic acid (ARA), and these can be converted back to the simpler species. This interconversion means the class rather than individual PUFAs is regarded as essential. The same principles apply to $\omega-6$ PUFAs. The essential fatty acids are abundant in fish, shellfish, nuts and leafy vegetables but they are not present in cereals (Farré et al. 2011b).

The fatty acid biosynthesis pathway in plants was modulated to produce $\omega-3$ and $\omega-6$ PUFAs by introducing the microbial enzymes responsible for a sequence of fatty acid desaturation and elongation reactions (Domergue et al. 2005). The key targets are linoleic acid and $\alpha$-linolenic acid, and the VLC-PUFAs ARA, eicosapentenoic acid 
(EPA) and docosahexenoic acid (DHA; Zhu et al. 2007). The biosynthesis of VLC-PUFAs has been achieved by expressing microbial desaturases and elongases in linseed, soybean and mustard (Abbadi et al. 2004; Kinney et al. 2004; Wu et al. 2005) with the experiments in mustard demonstrating the feasibility of a stepwise approach to first optimize the accumulation of $\omega$-3 fatty acids (i.e., EPA rather than ARA) and then to convert this to DHA, resulting in the accumulation of ARA (4\%), EPA ( $8 \%$ ) and DHA $(0.2 \%)$. These successes have led to the longterm goal of producing such fatty acids in transgenic oilseed crops (Abbadi et al. 2004; Domergue et al. 2005).

\section{GE strategies to enhance the content of mineral micronutrients}

Unlike organic nutrients, which are the product of plant metabolism, inorganic nutrients (minerals) must be taken up by plants from the environment. GE approaches to enhance mineral nutrients are therefore diverse, focusing on strategies such as increasing the solubility of these nutrients in the rhizosphere, mobilizing them in the plants, transporting them to storage organs, increasing the storage capacity of the plant, and maximizing bioavailability (Gómez-Galera et al. 2010). The four most significant minerals in terms of nutrient deficiency are iron, zinc, selenium and calcium. Other minerals, while no less essential, are so abundant and ubiquitous that deficiency disorders are very rare. It is not uncommon for populations to be deficient for several of the above minerals at the same time so there has been recent interest in the development of crops tailored to provide all these limiting nutrients simultaneously (Zhu et al. 2008; Naqvi et al. 2009a).

Iron

Iron deficiency is the most prevalent form of mineral malnutrition in the world, with more than 2 billion people at risk. The primary clinical manifestation is anemia, and it is estimated that more than half of all cases of anemia worldwide are caused by a lack of iron (Benoist et al. 2008).

Biofortification offers a more sustainable approach for subsistence farmers and many different strategies have been investigated (Drakakaki et al. 2005; Wirth et al. 2009). One of the major challenges with iron is that its mobility in the rhizosphere is dependent on the soil conditions, because only the ferrous form $\left(\mathrm{Fe}^{2+}\right)$ is soluble and bioavailable to plants whereas the ferric form $\left(\mathrm{Fe}^{3+}\right)$ is sequestered into insoluble complexes with soil particles (Gómez-Galera et al. 2012a). Plants have evolved two counterstrategies, one of which is to secrete reductases into the soil to convert ferric iron into the soluble ferrous form, and the other is to release chelating agents known as phytosiderophores (PS) that can be reabsorbed by the roots as PS-Fe ${ }^{3+}$ complexes. Iron levels in plants can therefore be improved by increasing the export of both reductases and phytosiderophores, for example, by overexpressing the enzymes nicotianamine synthase (NAS) and/or nicotianamine aminotransferase (NAAT) which are involved in phytosiderophore synthesis (Zheng et al. 2010; Johnson et al. 2011). For example, transgenic rice plants expressing the NAS genes Osnas1, Osnas2 or Osnas3 accumulated up to $19 \mu \mathrm{g} / \mathrm{g}$ of iron in the endosperm (Johnson et al. 2011, Table 1). Additional strategies include the overexpression of iron transporter proteins (many of which also co-transport zinc, see below), the overexpression of ferritin (which stores large amounts of iron in a bioavailable form) and the expression of phytase, which breaks down phytate and makes the stored iron easier to absorb in the human digestive system (see section on antinutritional factors, below).

\section{Zinc}

Zinc is required as a cofactor in many different enzymes and is also a coordinating ion in the DNA-binding domains of transcription factors. Zinc deficiency affects more than 2 billion people worldwide predominantly in developing countries and manifests as a spectrum of symptoms including hair loss, skin lesions, fluid imbalance (inducing diarrhea), and eventually wasting of body tissues (Hambidge and Krebs 2007).

Cereal grains are poor sources of zinc, but because this mineral is more soluble than iron and easier to take up from the soil, GE strategies to increase the zinc content of plants have concentrated on transport and accumulation (Palmgren et al. 2008). Many phytosiderophores and transporters can interact with both iron and zinc so the expression of NAS/NAAT and transporters such as Osysl15 and Osirtl in rice can increase the levels of both minerals (e.g., Lee et al. 2011, Table 1).

\section{Selenium}

Selenium is a component of enzymes and other proteins that contain the amino acids selenocysteine and selenomethionine, which are required for the interconversion of thyroid hormones; therefore selenium and iodine deficiency can have similar symptoms (Khalili et al. 2008). Selenium deficiency is rare at a population level because the mineral is taken up efficiently from the soil, and fertilizers with selenium have proven successful to prevent deficiency in areas where the soil is depleted (Lyons et al. 2003). GE strategies to increase selenium levels therefore focus on storage and accumulation. For example, the 
expression of Arabidopsis ATP sulfurylase in mustard increased the selenite content by up to threefold in roots and shoots (Pilion-Smits et al. 1999, Table 1).

\section{Calcium}

Soluble calcium is an electrolyte and signaling molecule, but most of the calcium in the human body is present in its mineralized form as a component of bones and teeth. The replenishment of serum calcium by bone resorption is slow, so dietary calcium deficiency in the short term can lead to electrolyte imbalance and over the long term can cause osteoporosis. The risk is higher in children as the rapid bone growth that occurs during childhood results in a high demand for calcium. Calcium-rich dairy products tend to be inaccessible in developing-country settings so many children and adults are malnourished (Dayod et al. 2010). Root vegetables and leafy crops such as lettuce are good sources of calcium although in some vegetables the high content of phytate and oxalate makes the calcium difficult to absorb (Jeong and Guerinot 2008). GE strategies to increase the calcium content of plants include the expression of calcium transporters such as AtCAX1, which increased the calcium content of carrots and potatoes by up to threefold (Connolly 2008; Park et al. 2005, Table 1).

\section{Nutrient enhancers and anti-nutrients}

A number of compounds are known to enhance or inhibit the absorption of plant minerals by the human digestive system, and mineral bioavailability can therefore be increased by promoting the accumulation of enhancers or eliminating anti-nutrients (Gibson 2007). Some key nutrients act as enhancers and therefore provide dual benefits, for example, ascorbate and $\beta$-carotene promote iron uptake by chelating and/or reducing $\mathrm{Fe}^{3+}$ and preventing interactions with phytate and polyphenols (García-Casal et al. 2000).

Phytic acid is a key anti-nutrient because it is abundant in cereals, legumes and oil seeds where it binds all the principal mineral nutrients and sequesters them into stable complexes that cannot be absorbed (Lopez et al. 2002). The amount of phytic acid in seeds can be reduced by silencing genes involved in its biosynthesis, such as myo-inositol-1phosphate synthase (Nunes et al. 2006) or 1D-myo-inositol 3 -phosphate synthase (Kuwano et al. 2009). Expression of a thermostable recombinant fungal phytase increased iron bioavailability in wheat (Brinch-Pedersen et al. 2006) and maize (Chen et al. 2008). Transgenic maize plants expressing phytase may well be the first second-generation GE crop to reach the market (Chen et al. 2008).

Cassava is an important staple crop in sub-Saharan Africa but the high content of the cyanogenic glycosides linamarin and lotaustralin means it must be processed before consumption (Jørgensen et al. 2005). Two genes encoding cytochrome P450s (CYP79D1 and CYP79D2) catalyze the first step in linamarin and lotaustralin synthesis, and suppression of these genes has reduced linamarin by $94 \%$ (Siritunga and Sayre 2003). RNA interference targeting the same genes reduced the cyanogenic glucoside content by $99 \%$ (Jørgensen et al. 2005).

\section{Risk assessment and regulation of GE crops}

Genetically engineered (GE) crops must undergo a risk assessment to assess their potential impact on human health and the environment before they receive market authorization (EFSA 2010). This involves detailed molecular characterization, comparison to conventional crops of the same species, assessment of potential toxicity/allergenicity and nutritional analysis (USFDA 1992; EFSA 2011). In most parts of the world, authorization follows automatically from a positive evaluation, but the decision-making process in the European Union (EU) has become politicized and it is now almost inevitable that regulatory approvals are ignored and overruled (Sabalza et al. 2011; Ramessar et al. 2010).

There are two key differences between the regulatory systems adopted in the EU (where few GE crops are approved) and in the US, where GE agriculture is strongly established and has an unblemished 15-year safety record (Ramessar et al. 2009). The first is that the US system focuses on the safety of the product compared to a conventional counterpart, whereas the EU system focuses instead on the process. This leads to two major conflicts of logic: (1) identical GE and conventional crops are subject to different tiers of regulation; and (2) imported GE products are regulated differently because they are not grown in the EU and are not under regulations applied to cultivation, that is, identical GE products are subject to different tiers of regulation according to origin. The second difference is that the US system is based on substantial equivalence, that is, a GE crop is approved if it is largely the same as its conventional counterpart and that the differences do not introduce clearly defined risks that can be demonstrated experimentally. In contrast, the EU system is based on the precautionary approach, which essentially means that a GE crop is not approved unless the absence of risk can be demonstrated. Since it is impossible to prove that a risk is zero (as opposed to vanishingly small) this creates an effective moratorium on GE agriculture in Europe.

The risk assessment of GE crops focuses on two main aspects-the potential effect on the environment and the potential effect on human health through consumption. 
Ostensibly the assessment criteria should be based on rational scientific premises but there remain several key areas where arbitrary factors are included, for example, the risk of gene transfer from plants to microbes in the environment, which is too low to quantify because there is no evidence for this process throughout millions of years of evolution yet it cannot be proven to be zero (Ramessar et al. 2007; EFSA 2010). Even EFSA itself acknowledges this inconsistency yet the requirement persists (EFSA 2009). It is also necessary to determine the risk posed by GE plants, their pollen and residues to agricultural workers when no adverse effects have been reported after 15 years of GE agriculture in the US, Argentina, Brazil, China and India, whereas similar risk assessments are not required for conventional crops, even those known to produce potentially harmful products such as alkaloids in tobacco and erucic acid in rapeseed and mustard oil (EFSA 2010).

GE crops must also undergo toxicological analysis to prove the absence of unintended effects using animal models (usually rodents) and this may be extended from acute tests to multigenerational chronic toxicity/reproductive tests if deemed appropriate (EFSA 2011).

The best known example of a nutritionally enhanced crop is Golden Rice (Ye et al. 2000), which was developed in 1999 but has been mired in regulatory bureaucracy ever since despite the successful completion of multiple safety assessments in silico, in vitro, in animal models and in human trials (Tang et al. 2009). Golden Rice therefore provides an excellent example of the major deficiency in current regulatory processes, that is, that they focus on the risks rather than a risk-benefit analysis (Kowalski 2007). Genetic engineering reduces the time and cost required for developing plants enhanced with one or several traits, but these savings are compromised by the long and costly regulatory process that is not applied to conventional varieties even if they incorporate exactly the same traits and use similarly "unnatural" processes such as forced hybridization or chemical mutagenesis (Sabalza et al. 2011).

\section{Functionality testing}

The ultimate success of biofortification can only be judged by its impact on human health and nutrition after deployment (König et al. 2004). The anti-nutritional factors discussed earlier prevent the digestion, absorption and/or utilization of nutrients, so GE crops must undergo bioavailability studies to predict their impact at the population level, and this is also an important part of the regulatory process (Hirschi 2008).

The bioavailability of micronutrients in a staple crop depends on overlapping diet and host-related factors such as co-consumed foods, the geographical region, and the efficiency with which individual consumers absorb certain nutrients (Gibson 2007). Diet-related factors, which predominantly reflect interactions among micronutrients and other organic compounds, have a profound effect on the efficiency of a nutritionally enhanced crop (Graham et al. 2001). Such factors include the chemical form (speciation) of the nutrient, for example, selenomethionine is a more bioavailable form of selenium than any inorganic source (Combs 2001) and heme-iron from meat is much more bioavailable than the non-heme iron from cereals and legumes (Monsen and Balintfy 1982).

\section{Constraints preventing adoption}

Nutritionally enhanced GE crops have an enormous potential to tackle poverty, malnutrition and ill health particularly in the developing world, but there are several constraints preventing their adoption, cultivation and use. The development of crops with higher levels of key nutrients requires the simultaneous transfer and expression of multiple transgenes in local varieties, which may be recalcitrant to GE approaches. This requirement becomes even more complex if several nutritional components are addressed at the same time (Naqvi et al. 2009a, 2010; Zhu et al. 2008; Farré et al. 2011a).

As well as technical limitations, a further constraint to the adoption of nutritionally enhanced GE crops is their potential socioeconomic impact. The first generation of GE crops provided substantial economic benefits for farmers in developed and developing countries (Qaim 2009; Brookes and Barfoot 2006) and second-generation crops are expected to provide similar socio-economic benefits although favoring the consumer as well as the producer (Qaim et al. 2007). Even so, the costs of development (predominantly regulatory compliance) can exceed $\$ 15$ million (Kalaitzandonakes et al. 2007) which blocks the approval pathway de facto for public sector institutions and small and medium companies that lack the financial resources of the agro-industry. Only few major companies have the economic muscle to complete the regulatory process, and R\&D investment will not be recouped from humanitarian projects (Lemaux 2009). This limits the incentive to invest in GE products tailored for developing countries (Qaim et al. 2007; Qaim 2009).

EU legislation for the approval of GE crops (Directive 2001/18/EC and Regulation EC 1829/2003) also acts as a constraint because it is highly politicized and driven by single-interest groups such as the organic farming lobby and environmental activists rather than rational scientific discourse (Apel 2010). The regulatory pipeline requires years to negotiate even if the applicant has unlimited funds 
and precise legal knowledge, and acts as a barrier for testing, scientific investigations and commercial production (Kalaitzandonakes et al. 2007; Gómez-Galera et al. 2012b).

Perhaps the most insidious problem with the adoption of nutritionally enhanced GE crops is that this potentially lifesaving scientific breakthrough has become the flagship campaign for activists, who appear to have garnered public opinion and thus have a disproportionate effect on politicians, who in turn determine the rules followed by the regulators. The unfortunate consequence of this negative cycle is that the regulations are changing under political influence to make any kind of GE agriculture almost impossible in Europe. For example, the European Parliament recently published a proposal to allow EU member states the opportunity to opt out of GE agriculture without any scientific justification, ostensibly to prevent single member states vetoing cultivation throughout Europe. However, the politicians have overlooked the negative impact this decision would have on the acceptability of GE crops to the public (Sabalza et al. 2011; Morris and Spillane 2010). The EU already labors under scientifically unjustified coexistence measures, including excessive isolation distances for GE crops and unmanageable adventitious presence thresholds that cause trade conflicts with other countries (Ramessar et al. 2009, 2010). Within this hostile environment there is no voice for scientists and indeed no voice for science, a worrying glimpse of a future dark age where superstition and hearsay are more important than facts, and those that bear the consequences are the world's poor who do not have the luxury of choice and will continue to suffer from malnutrition for the foreseeable future (Farré et al. 2010a, 2011b).

\section{Future prospects}

The world population will reach 10.5 billion in 2050, with most of the population increase in developing countries. Global food production will need to increase by $70 \%$, including 3 billion tons of cereals, which means global rice and maize production must double even as the land available for agriculture shrinks in the face of urbanization, land degradation and dwindling access to water (FAO 2009). Future food security therefore depends on our ability to improve the quality as well as the quantity of food and to reduce the global health burden of micronutrient deficiency disease. This will require multidisciplinary collaboration between stakeholders such as farmers, health providers, nutrition experts, plant breeders, the food and agrochemical industries, the biotechnology industry, governments and NGOs to reduce the impact of malnutrition on human populations (Martin et al. 2011).
We also need to increase awareness of the environmental and health benefits of GE crops, which are rarely discussed in the media, such as reduced pesticide and fossil fuel usage in agriculture, reduced mycotoxin levels, and reduced exposure to toxic agrochemicals (Raybould and Quemada 2010; Sanahuja et al. 2011). For example, the planting of Bt cotton has reduced pesticide applications by $50 \%$ in India, avoiding up to 9 million poisoning incidents and saving \$51 million (Kouser and Qiam 2011). Bt corn also has lower levels of mycotoxins (e.g., fumonisin), saving \$23 million annually in crop losses (Wu 2006). Nutritional traits therefore need to be combined with firstgeneration input traits for maximum benefit (Sun et al. 2004).

Another key future development will be the provision of incentives to develop nutritionally enhanced orphan crops, that is, crops such as finger millet, cassava and fonio that are grown on a small scale in niche geographical areas (Online Resource 6). These crops have not been studied in detail and generally produce lower yields and nutritionally poorer or more toxic products than staple crops (Tadele 2009). With sufficient targeted resources they could yet be developed into alternative staples for niche geographical areas (Naylor et al. 2004).

Many developing countries have followed EU protectionism and banned GE products due to consumer and environmental concerns, for example, the moratorium on GE eggplant in India (Chong 2011), putting millions of lives at risk from malnutrition and the continuous indiscriminate use of toxic pesticides (Ramaswami 2007). There needs to be a shift from risk assessment to risk-benefit analysis, which is applied in all other technology areas (Ramessar et al. 2009). We need to establish a globally harmonized risk-benefit system that is based on traits rather than events (the product not the process). Furthermore, the Cartagena Protocol on Biosafety needs to be redesigned to reflect the reality of global food security challenges and to address the issue of GE crops specifically, as the current protocol does not consider GE foods that are outside the definition of a living modified organism. We need to remove the precautionary approach and other non-science-based doctrines in the context of nutritionally enhanced crops to ensure they can be deployed where they are needed the most and where they can get on with the important task of saving lives.

\section{References}

Abbadi A, Domergue F, Bauer J, Napier JA, Welti R, Zähringer U, Cirpus P, Heinz E (2004) Biosynthesis of very-long-chain polyunsaturated fatty acids in transgenic oilseeds: constraints on their accumulation. Plant Cell 16:2734-2748 
Aluru M, Xu Y, Guo R et al (2008) Generation of transgenic maize with enhanced provitamin A content. J Exp Bot 59:3551-3562

Apel A (2010) The costly benefits of opposing agricultural biotechnology. New Biotechnol 27:635-640

Bai C, Twyman RM, Farré G, Sanahuja G, Christou P, Capell T, Zhu C (2011) A golden era-pro-vitamin A enhancement in diverse crops. In Vitro Cell Dev Biol Plant 47:205-221

Bartholomew M (2002) James Lind's treatise of the scurvy (1753). Postgrad Med J 78:695-696

Benoist B, McLean M, Egli I, Cogswell M (2008) Worldwide prevalence of anaemia 1993-2005. WHO Global database on Anaemia

Bicar E, Woodman-Clikeman W, Sangtong V, Peterson J, Yang S, Lee M, Scott M (2008) Transgenic maize endosperm containing a milk protein has improved amino acid balance. Transgenic Res 17:59-71

Botella-Pavía P, Rodríguez-Concepción M (2006) Carotenoid biotechnology in plants for nutritionally improved foods. Physiol Plantarum 126:369-381

Brinch-Pedersen H, Hatzack F, Stöger E, Arcalis E, Pontopidan K, Holm PB (2006) Heat-stable phytases in transgenic wheat (Triticum aestivum L.): deposition pattern, thermostability, and phytate hydroslysis. J Agric Food Chem 54:4624-4632

Brookes G, Barfoot P (2006) GM crops: the first ten years-global socio-economic and environmental impacts. ISAAA Brief 36, ISAAA, Ithaca

Bulley S, Wright M, Rommens C, Yan H et al (2011) Enhancing ascorbate in fruits and tubers through over-expression of the L-galactose pathway gene GDP-L-galactose phosphorylase. Plant Biotechnol J 10:390-397

Chakraborty S, Chakraborty N, Datta A (2000) Increased nutritive value of transgenic potato by expressing a nonallergenic seed albumin gene from Amaranthus hypochondriacus. Proc Natl Acad Sci USA 97:3724-3729

Chen R, Xue G, Chen P, Yao B, Yang W, Ma Q, Fan Y, Zhao Z, Tarczynski MC, Shi J (2008) Transgenic maize plants expressing a fungal phytase gene. Transgenic Res 17:633-643

Cho EA, Lee CA, Kim YA, Baek SH, Reyes BG, Yun SJ (2005) Expression of $\gamma$-tocopherol methyltransferase transgene improves tocopherol composition in lettuce (Latuca sativa L.). Mol Cells 19:16-22

Chong MYK (2011) Risk perception and communication about agricultural biotechnology in developing countries: the case of Bt eggplant in India. Cornwell University, Dissertation

Christou P, Twyman RM (2004) The potential of genetically enhanced plants to address food insecurity. Nutr Res Rev $17: 23-42$

Combs GF Jr (2001) Selenium in global food systems. Br J Nutr 85:517-547

Cong L, Wang C, Chen L, Liu H, Yang G, He G (2009) Expression of phytoene synthase 1 and carotene desaturase crtI genes result in an increase in the total carotenoids content in transgenic elite wheat (Triticum aestivum L.). J Agric Food Chem 57:8652-8660

Connolly EL (2008) Raising the bar for biofortification: enhanced levels of bioavailable calcium in carrots. Trends Biotechnol 26:401-403

Dayod M, Tyerman SD, Leigh RA, Gilliham M (2010) Calcium storage in plants and the implications for calcium biofortification. Protoplasma 247:215-231

DellaPenna D, Pogson B (2006) Vitamin synthesis in plants: tocopherols and carotenoids. Ann Rev Plant Biol 57:711-773

Díaz de la Garza R, Gregory JF, Hanson AD (2007) Folate biofortification of tomato fruit. Proc Natl Acad Sci USA 104:4218-4222

Diretto G, Al-Babili S, Tavazza R, Papacchioli V, Beyer P, Giuliano G (2007) Metabolic engineering of potato carotenoid content through tuber-specific overexpression of a bacterial mini-pathway. PLoSONE 2:e350

Djoussé L, Biggs ML, Lemaitre RN, King IB, Song X, Ix JH, Mukamal KJ, Siscovick DS, Mozaffarian D (2011) Plasma omega-3 fatty acids and incident diabetes in older adults. Am J Clin Nutr 94:527-533

Domergue F, Abbadi A, Heinz E (2005) Relief for fish stocks: oceanic fatty acids in transgenic oilseeds. Trends Plant Sci 10:112-116

Drakakaki G, Marcell S, Glahn RP, Lund EK, Pariagh S, Fischer R, Christou P, Stoger E (2005) Endosperm-specific co-expression of recombinant soybean ferritin and Aspergillus phytase in maize results in significant increases in the levels of bioavailable iron. Plant Mol Biol 59:869-880

Ducreux LJ, Morris WL, Hedley PE, Shepherd T, Davies HV, Millam S, Taylor MA (2005) Metabolic engineering of high carotenoid potato tubers containing enhanced levels of beta-carotene and lutein. J Exp Bot 56:81-89

EFSA Panel on Genetically Modified Organisms (GMO) (2010) Guidance on the environmental risk assessment of genetically modified plants. EFSA J 2010(8):1879-1989

EFSA Panel on Genetically Modified Organisms (GMO) (2011) Guidance for risk assessment of food and feed from genetically modified plants. EFSA J 2011(9):2150-2186

EFSA Panel on Genetically Modified Organisms (GMO) and Panel on Biological Hazards (BIOHAZ) (2009) Scientific opinion on a request from the European Commission on the use of antibiotic resistance genes as marker genes in genetically modified plants. EFSA J 2009(1034):1-81

Enfissi EMA, Fraser PD, Lois LM, Boronat A, Schuch W, Bramley PM (2005) Metabolic engineering of the mevalonate and nonmevalonate isopentenyl diphosphate-forming pathways for the production of health-promoting isoprenoids in tomato. Plant Biotechnol J 3:17-27

FAO (2009) 2050: A third more mouths to feed: food production will have to increase by 70 percent-FAO convenes high-level expert forum. FAO Media centre, Rome

Farré G, Ramessar K, Twyman RM, Capell T, Christou P (2010a) The humanitarian impact of plant biotechnology: recent breakthroughs vs bottlenecks for adoption. Curr Opin Plant Biol 13:219-225

Farré G, Sanahuja G, Naqvi S, Bai C, Capell T, Zhu C, Christou P (2010b) Travel advice on the road to carotenoids in plants. Plant Sci 179:28-48

Farré G, Bai C, Twyman RM, Capell T, Christou P, Zhu C (2011a) Nutritious crops producing multiple carotenoids-a metabolic balancing act. Trends Plant Sci 16:532-540

Farré G, Twyman RM, Changfu Z, Capell T, Christou P (2011b) Nutritionally enhanced crops and food security: scientific achievements versus political expediency. Curr Opin Biotechnol $22: 245-251$

Farré G, Sudhakar D, Naqvi S, Sandmann G, Christou P, Capell T, Zhu C (in press) Transgenic rice grains expressing a heterologous $\rho$-hydroxyphenylpyruvate dioxygenase shift tocopherol synthesis from the gamma to the alpha isoform without increasing absolute tocopherol levels. Trans Res. doi:10.1007/ s11248-012-9601-7

Frizzi A, Huang S, Gilberton LA, Armstrong TA, Luethy MH, Malvar TM (2008) Modifying lysine biosynthesis and catabolism in corn with a single bifuncitonal expression/silencing transgene cassette. Plant Biotechnol J 6:13-21

García-Casal MN, Leets I, Layrisse M (2000) $\beta$-carotene and inhibitors of iron absorption modify iron uptake by Caco-2 cells. J Nutr 130:5-9

Gibson RS (2007) The role of diet- and host-related factors in nutrient bioavailability and thus in nutrient-based dietary requirement estimates. Food Nutr Bull 28:77-100 
Gómez-Galera S, Rojas E, Sudhakar D, Zhu C, Pelacho AM, Capell T, Christou P (2010) Critical evaluation of strategies for mineral fortification of staple crops. Transgenic Res 19:165-180

Gómez-Galera S, Sudhakar D, Pelacho AM, Capell T, Christou P (2012a) Constitutive expression of a barley Fe phytosiderophore transporter increases alkaline soil tolerance and results in iron partitioning between vegetative and storage tissues under stress. Plant Physiol Biochem 53:46-53

Gómez-Galera S, Twyman RM, Sparrow PAC, Van Droogenbroeck B, Custers R, Capell T, Christou P (2012b) Field trials and tribulations-making sense of the regulations for experimental field trials of transgenic crops in Europe. Plant Biotechnol J 10:511-523

Graham RD, Welch RM, Bouis HE (2001) Addressing micronutrient malnutrition through enhancing the nutritional quality of staple foods: principles, perspectives and knowledge gaps. Adv Agron 70:77-142

Hambidge MK, Krebs NF (2007) Zinc deficiency: a special challenge. J Nutr 137:1101-1105

Harrison EA (2005) Mechanisms of digestion and absorption of dietary vitamin A. Annu Rev Nutr 25:87-103

Hemavathi UpadhyayaCP, Akula N, Young KE, Chun SC, Hwan Kim D, Park SW (2010) Enhanced ascorbic acid accumulation in transgenic potato confers tolerance to various abiotic stresses. Biotechnol Lett 32:321-330

Hirschi K (2008) Nutritional improvements in plants: time to bite on biofortified foods. Trends Plant Sci 13:459-463

Hoddinott J, Maluccio JA, Behrman JR, Flores R, Martorell R (2008) Effect of a nutrition intervention during early childhood on economic productivity in Guatemalan adults. Lancet 371: $411-416$

Hotz C, Brown KH (2004) Assessment of the risk of zinc deficiency in population and options for its control. Food Nutr Bull 25:99-203

Hotz C, Gibson RS (2007) Traditional food-processing and preparation practices to enhance the bioavailability of micronutrients in plant-based diets. J Nutr 137:1097-1100

Ishimoto M, Rahman SM, Hanafy MS, Khalafalla MM, El-Shemy HA, Nakamoto Y, Kita Y, Takanashi K, Matsuda F, Murano Y, Funabashi T, Miyagawa H, Wakasa K (2010) Evaluation of amino acid content and nutritional quality of transgenic soybean seeds with high-level tryptophan accumulation. Mol Breed 25:313-326

Jain AK, Nessler CL (2000) Metabolic engineering of an alternative pathway for ascorbic acid biosynthesis in plants. Mol Breed 6:73-78

Jeong J, Guerinot ML (2008) Biofortified and bioavailable: the gold standard for plant-based diets. Proc Nac Acad Sci USA 105:1777-1778

Johnson AAT, Kyriacou B, Callahan DL, Carruthers L, Stangoulis J, Lombi E, Tester M (2011) Constitutive overexpression of the OsNAS gene family reveals single-gene strategies for effective iron- and zinc-biofortification of rice endosperm. PLOSone 6:e24476

Jørgensen K, Bak S, Kamp Busk P, Sørensen C, Olsen CE, PuontiKaerlas J, Lindberg Møller B (2005) Cassava plants with a depleted cyanogenic glucoside content in leaves and tubers. distribution of cyanogenic glucosides, their site of synthesis and transport, and blockage of the biosynthesis by RNA interference technology. Plant Physiol 139:363-374

Jung R, Carl F (2000) Transgenic corn with an improved amino acid composition. In: Müntz K, Ulrich W (eds) The 8th international symposium on plant seeds. Institute of Plant Genetics and Crop Plant Research, Gatersleben

Kalaitzandonakes N, Alston JM, Bradford KJ (2007) Compliance costs for regulatory approval of new biotech crops. Nature Biotecnol 25:509-511
Khalili H, Soudbakhsh A, Hajiabdolbaghi M, Dashti-Khavidaki S, Poorzare A, Saeedi AA, Sharififar R (2008) Nutritional status and serum zinc and selenium levels in Iranian HIV infected individuals. J Infect Dis 8:165-172

Kim CK, Han JS, Lee HS, Oh JY et al (2006) Expression of an Arabidopsis CAX2 variant in potato tubers increases calcium levels with no accumulation of manganese. Plant Cell Rep 25:1226-1232

Kinney AJ, Cahoon EB, Damude HG, Hitz WD, Kolar CW, Liu ZB (2004) Production of very long chain polyunsaturated fatty acids in oilseed plants. Patent WO 071467 A2

König A, Cockburn A, Crevel RWR, Debruyne E, Grafstroem R, Hammerling U, Kimber I, Knudsen I, Kuiper HA, Peijnenburg AACM, Penninks AH, Poulsen M, Schauzu M, Wal JM (2004) Assessment of the safety of food derived from genetically modified GM crops. Food Chem Toxicol 42:1047-1088

Kouser S, Qiam M (2011) Impact of Bt cotton on pesticide poisoning in smallholder agriculture: a panel data analysis. Ecol Econom 70:2105-2113

Kowalski S (2007) Rational risk/benefit analysis of genetically modified crops. J Intellect Prop Rights 12:92-103

Kuwano M, Mimura T, Takaiwa F, Yoshida KT (2009) Generation of stable 'low phytic acid' transgenic rice through antisense repression of the 1D-myo-inositol 3-phosphate synthase gene (RINO1) using the 18-kDa oleosin promoter. Plant Biotechnol J 7:96-105

LeDuc DL, Tarun AS, Montes-Bayon M, Meija J et al (2004) Overexpression of selenocysteine methyltransferase in Arabidopsis and Indian mustard increases selenium tolerance and accumulation. Plant Physiol 135:377-383

Lee S, Jeon US, Lee SJ, Kim YK, Persson DP et al (2009) Iron fortification of rice seeds through activation of the nicotianamine synthase gene. Proc Natl Acad Sci USA 106:22014-22019

Lee S, Persson DP, Hansen TH, Husted S, Schjoerring JK, Kim YS, Jeon US, Kim YK, Kakei Y, Masuda H, Nishizhawa NK, An G (2011) Bio-available zinc in rice seeds is increased by activation tagging of nicotianamine synthase. Plant Biotechnol J 9:865-873

Lemaux PG (2009) Genetically engineered plants and food: scientist's analysis of the issues (part II). Ann Rev Plant Biol 60:511-599

Lopez HW, Leenhardt F, Coudray C, Remesy C (2002) Minerals and phytic acid interactions: is it a real problem for human nutrition? Int J Food Sci Technol 37:727-739

Lopez AB, Eck JV, Conlin BJ, Paolillo DJ, O’Neill J, Li L (2008) Effect of the cauliflower Or transgene on carotenoid accumulation and chromoplast formation in transgenic potato tubers. J Exp Bot 59:213-223

Lyons G, Stangoulis J, Graham R (2003) High-selenium wheat: biofortification for better health. Nutr Res Rev 16:45-60

Martin C, Butelli E, Petroni K, Tonelli C (2011) How can research on plants contribute to promoting human health? Plant Cell 23:1685-1699

Monsen ER, Balintfy J (1982) Calculating dietary iron bioavailability: refinement and computerization. J Am Diet Assoc 80:307-311

Morris S, Spillane C (2010) EU GM crop regulation: a road to resolution or a regulatory roundabout? EJRR 4:359

Naqvi S, Farre G, Sanahuja G, Capell T, Zhu C, Christou P (2009a) When more is better: multigene engineering in plants. Trends Plant Sci 15:49-56

Naqvi S, Zhu C, Farre G, Ramessar K, Bassie L, Breitenbach J, Conesa D, Ros G, Sandmann G, Capell T, Christou P (2009b) Transgenic multivitamin corn through biofortification of endosperm with three vitamins representing three distinct metabolic pathways. Proc Natl Acad Sci USA 106:7762-7767

Naqvi S, Zhu C, Farre G, Sandmann G, Capell T, Christou P (2010) Synergistic metabolism in hybrid corn indicates bottlenecks in the carotenoid pathway and leads to the accumulation of 
extraordinary levels of the nutritionally important carotenoid zeaxanthin. Plant Biotechnol J 9:384-393

Naqui S, Farré G, Zhu C, Sandmann G, Capell T, Christou P (2011) Simultaneous expression of Arabidopsis $\rho$-hydroxyphenylpyruvate dioxygenase and MPBQ methyltransferase in transgenic corn kernels triples the tocopherol content. Transgenic Res 20:177-181

Naylor RL, Falcon WP, Goodman RM, Jahn MM, Sengooba T, Tefera H, Nelson RJ (2004) Biotechnology in the developing world: a case for increased investments in orphan crops. Food Policy 29:15-44

Nunes ACS, Vianna GR, Cuneo F, Amaya-Farfán J, de Capdeville G, Rech EL, Aragao FJL (2006) RNAi-mediated silencing of the myo-inositol-1-phosphate synthase gene (GmMIPS1) in transgenic soybean inhibited seed development and reduced phytate content. Planta 224:125-132

Paine J, Shipton C, Chaggar S, Howells R, Kennedy M, Vernon G, Wright S, Hinchliffe E, Adams J, Silverstone A, Drake R (2005) Improving the nutritional value of Golden Rice through increased pro-vitamin A content. Nat Biotechnol 23:482-487

Palmgren MG, Clemens S, Williams LE, Krämer U, Borg SUK, Schjørring JK, Sanders D (2008) Zinc biofortification of cereals: problems and solutions. Trends Plant Sci 13:464-473

Park SH, Kim C-K, Pike LM et al (2004) Increased calcium in carrots by expression of an Arabidopsis $\mathrm{H}+/ \mathrm{Ca} 2+$ transporter. Mol Breed 14:275-282

Park S, King TS, Kim CK, Han JS, Kim S, Smith RH, Pike LM, Hirschi KD (2005) Genetic manipulation for enhancing calcium content in potato tuber. J Agric Food Chem 53:5598-5603

Park S, Elless MP, Park J et al (2009) Sensory analysis of calciumbiofortified lettuce. Plant Biotechnol J 7:106-117

Perseley G (2000) Agricultural biotechnology and the poor: Promethean science. In: Perseley GJ, Lantin MM (eds) Agricultural biotechnology and the poor: proceedings of an international conference, Washington, DC, 21-22 October 1999. Consultative Group on International Agricultural Research, Washington, DC, pp 1-36

Pilion-Smits EAH, Hwang S, Lytle CM, Zhu Y, Tai JC, Bravo RC, Chen Y, Leustek T, Terry N (1999) Over expression of ATP sulfurylase in Indian mustard leads to increased selenate uptake, reduction and tolerance. Plant Physiol 119:123-132

Qaim M (2009) Economics of GM Crops. Ann Rev Resour Econ $1: 665-693$

Qaim M, Stein AJ, Meenakshi JV (2007) Economics of biofortification. Agric Econ 37:119-133

Ramaswami B (2007) Biofortified crops and biotechnology: a political economy landscape for India. AgBioForum 10: 170-177

Ramessar K, Peremarti A, Gómez-Galera S, Naqvi S, Moralejo M, Muñoz P, Capell T, Christou P (2007) Biosafety and risk assessment framework for selectable marker genes in transgenic crop plants: a case of the science not supporting the politics. Transgenic Res 16:261-280

Ramessar K, Capell T, Twyman RM, Quemada H, Christou P (2009) Calling the tunes on transgenic crops: the case for regulatory harmony. Mol Breeding 23:99-112

Ramessar K, Capell T, Twyman RM, Christou P (2010) Going to ridiculous lengths-European coexistence regulations for GM crops. Nat Biotechnol 28:133-136

Rascón-Cruz Q, Sinagawa-García S, Osuna-Castro JA, Bohorova N, Paredes-Lopez O (2004) Accumulation, assembly, and digestibility of amarantin expressed in transgenic tropical maize. Theor Appl Genet 108:335-342

Raybould A, Quemada H (2010) Bt crops and food security in developing countries: realized benefits, sustainable use and lowering barriers to adoption. Food Sec 2:247-259
Romer S, Lubeck J, Kauder F et al (2002) Genetic engineering of a zeaxanthin-rich potato by antisense inactivation and co-suppression of carotenoid epoxidation. Metab Eng 4:263-272

Rosenberg IH (2005) Science-based micronutrient fortification: which nutrients, how much, and how to know? Am J Clin Nutr 280:279-280

Sabalza M, Miralpeix B, Twyman RM, Capell T, Christou P (2011) EU legitimizes GM crop exclusion zones. Nature Biotechnol 29:315-317

Sanahuja G, Banakar R, Twyman RM, Capell T, Christou P (2011) Bacillus thuringiensis: a century of research, development and commercial applications. Plant Biotechnol J 9:283-300

Sayre R, Beeching JR, Cahoon EB, Egesi C et al (2011) The BioCassava plus program: biofortification of cassava for subSaharan Africa. Ann Rev Plant Biol 62:251-272

Scholl TO, Johnson GW (2000) Folic acid: influence on the outcome of pregnancy. Am J Clin Nutr 71:1295S-1303S

Segal G, Song R, Messing J (2003) A new opaque variant of maize by a single dominant RNA-interference-inducing transgene. Genetics 165:387-397

Sindhu AS, Zheng ZW, Murai N (1997) The pea seed storage protein legumin was synthesized, processed and accumulated stably in transgenic rice endosperm. Plant Sci 130:189-196

Siritunga D, Sayre RT (2003) Generation of cyanogens-free transgenic cassava. Planta 217:367-373

Stöger E, Parker M, Christou P, Casey R (2001) Pea legumin overexpressed in wheat endosperm assembles into an ordered paracrystalline matrix. Plant Physiol 125:1732-1742

Storozhenko S, De Brouwer V, Volckaert M, Navarrete O, Blancquaert D, Zhang GF, Lambert W, Van Der Straeten D (2007) Folate fortification of rice by metabolic engineering. Nat Biotechnol 25:1277-1279

Sun X, Cao Y, Yang Z, Xu C, Li X, Wang S, Zhang Q (2004) Xa26, a gene conferring resistance to Xanthomonas oryzae pv oryzae in rice, encodes an LRR receptor kinase-like protein. Plant J 37:517-527

Tadele Z (2009) New approaches to plant breeding of orphan crops in Africa. In: Proceedings of an international conference, 19-21 September 2007, Bern, Switzerland

Tamás C, Kisgyörgy BN, Rakszegi M, Wilkinson MD, Yang M, Láng L, Tamás L, Bedo Z (2009) Transgenic approach to improve wheat (Triticum aestivum L.) nutritional quality. Plant Cell Rep 28:1085-1094

Tang G, Qin J, Dolnikowski GG, Russell RM, Grusak MA (2009) Golden rice is an effective source of vitamin A. Am J Clin Nutr 89:1776-1783

Tavya V, Kim Y, Kagan I, Dinkins R, Kim K, Collins G (2007) Increased $\alpha$-tocopherol content in soybean seed overexpressing the Perilla frutescens $\gamma$-tocopherol methyltransferase gene. Plant Cell Rep 26:61-70

United States Food and Drug Administration (1992) Statement of policy—foods derived from new plant varieties. FDA federal register 57

Wakasa K, Hasegawa H, Nemoto H, Matsuda F, Miyazawa H, Tozawa Y, Morino K, Komatsu A, Yamada T, Terakawa T, Miyagawa H (2006) High-level tryptophan accumulation in seeds of transgenic rice and its limited effects on agronomic traits and seed metabolite profile. J Expt Bot 57:3069-3078

Welch RM, Graham RD (2005) Agriculture: the real nexus for enhancing bioavailable micronutrients in food crops. J Trace Element Med Biol 18:299-307

Welsch R, Arango J, Bar C, Salazar B, Al-Babili S, Beltran J, Chavarriaga P, Ceballos H, Tohme J, Beyer P (2010) Provitamin A accumulation in cassava (Manihot esculenta) roots driven by a single nucleotide polymorphism in a phytoene synthase gene. Plant Cell 22:3348-3356 
Wirth J, Poletti S, Aeschlimann B, Yakandawala N, Drosse B, Osorio S, Tohge T, Fernie AR, Günther D, Gruissem W, Sautter C (2009) Rice endosperm iron biofortification by targeted and synergistic action of nicotianamine synthase and ferritin. Plant Biotechnol J 7:631-644

Wu F (2006) Mycotoxin reduction in Bt corn: potential economic, health, and regulatory impacts. Transgenic Res 15:277-289

Wu G, Truksa M, Datla N, Vrinten P, Bauer J, Zank T, Cirpus P, Qiu $X$ (2005) Stepwise engineering to produce high yields of very long-chain polyunsaturated fatty acids in plants. Nat Biotechnol 23:1013-1017

Wu XR, Kenzior A, Willmot D, Scanlon S, Chen Z, Topin A, He SH, Acevedo A, Folk WR (2007) Altered expression of plant lysyl tRNA synthetase promotes tRNA misacylation and translation recoding of lysine. Plant J 50:627-663

Yamada T, Tozawa Y, Hasegawa H, Terakawa T, Ohkawa Y, Wakasa K (2004) Use of a feedback-insensitive a subunit of anthranilate synthase as a selectable marker for transformation of rice and potato. Mol Breed 14:363-373

Yang RY, Tsou SCS (2006) Enhancing iron bioavailability of vegetables through proper preparation-principles and applications. AVRDC-The World Vegetable Center, Taiwan. J International Cooperation 1:107-119

Ye X, Al-Babili S, Klöti A, Zhang J, Lucca P, Beyer P, Potrykus I (2000) Engineering the provitamin A (beta-carotene) biosynthetic pathway into (carotenoid-free) rice endosperm. Science 287:303-305
Yu J, Peng P, Zhang X, Zhao Q, Zhu D, Sun X, Liu J, Ao G (2004) Seed-specific expression of a lysine rich protein sb401 gene significantly increases both lysine and total protein content in maize seeds. Mol Breed 14:1-7

Yuan D, Bassie L, Sabalza M, Miralpeix B, Dashevskaya S, Farre G, Rivera SM, Banakar R, Bai C, Sanahuja G, Arjo G, Avilla E, Zorrilla-López U, Ugidos-Damboriena N, López A, Almacellas D, Zhu C, Capell T, Hahne G, Twyman RM, Christou P (2011) Potential impact of plant biotechnology on the Millennium Development Goals. Plant Cell Rep 30:249-265

Zheng L, Chengz AiC, Jiang X, Bei X, Zheng Y, Glahn RP, Welch RP, Miller DD, Lei XG, Shou H (2010) Nicotianamine, a novel enhancer of rice iron bioavailability to humans. PLoS ONE 5:e10190

Zhu C, Naqvi S, Gomez-Galera S, Pelacho AM, Capell T, Christou P (2007) Transgenic strategies for the nutritional enhancement of plants. Trends Plant Sci 12:548-555

Zhu C, Naqvi S, Breitenbach J, Sandman G, Christou P, Capell T (2008) Combinatorial genetic transformation generated a library of metabolic phenotypes for the carotenoid pathway in maize. Proc Natl Acad Sci USA 105:18232-18237

Zhu C, Naqvi S, Capell T, Christou P (2009) Metabolic engineering of ketocarotenoid biosynthesis in higher plants. Arch Biochem Biophys 483:182-190 